\title{
Analisis Dislikes to Viewers Ratio YouTube Pada 5 Klub Sepakbola Terkaya di Dunia
}

\author{
Muhammad Nawwaf Ansyori \\ bigbosshugoboss@gmail.com
}

\begin{abstract}
YouTube is a social media application that allows users to view, send and share videos. Based on data compiled by We Are Social, it has been recorded that $88 \%$ of Indonesians have used the social media Youtube. This means that out of 150 million social media users in Indonesia, around 132 million people already use YouTube. The large number of active YouTube users around the world can certainly provide an opportunity for famous football clubs to make the YouTube platform a social media marketing platform. The 5 richest football clubs in the world that use YouTube as a marketing platform are: Barcelona, Real Madrid, Bayern Munich, Manchester United and Liverpool. The purpose of this study is to calculate the credibility of the YouTube channel's performance of the 5 Richest Football Clubs in the World. The method used for this research is quantitative exploratory method. The results of this study indicate that the Bayern Munich football club is ranked first and has good channel performance credibility.
\end{abstract}

\section{ABSTRAK}

YouTube merupakan aplikasi sosial media yang memungkinkan penggunanya untuk melihat, mengirim dan berbagi video. Berdasarkan data yang dihimpun oleh We Are Social telah tercatat bahwa $88 \%$ orang Indonesia telah menggunakan media sosial Youtube. Ini artinya bahwa dari 150 juta penggguna media social di Indonesia, sekitar 132 juta orang sudah menggunakan YouTube. Banyaknya jumlah pengguna YouTube yang aktif di seluruh dunia tentu dapat memberikan peluang bagi klub sepakbola terkenal untuk menjadikan platform YouTube sebagai platform social media marketing. Adapun 5 klub sepakbola terkaya di dunia yang memanfaatkan YouTube sebagai platform marketing, yaitu : Barcelona, Real Madrid, Bayern Munich, Manchester United dan Liverpool. Tujuan dari penelitian ini yaitu untuk menghitung kredibilitas dari performa channel YouTube 5 Klub Sepakbola Terkaya di Dunia. Metode yang digunakan untuk penelitian ini yaitu metode eksploratif kuantitatif. Hasil dari penelitian ini menunjukan bahwa klub sepakbola Bayern Munich mendapatkan peringkat pertama dan memiliki kredibilitas performa channel yang baik. 
Keywords : YouTube ; Social Media ; Football Club ; Dislikes to Viewers Ratio ; Variable.

\section{PENDAHULUAN}

Media sosial adalah sebuah media online, yang para penggunanya bisa dengan mudah berpartisipasi, berbagi, dan menciptakan. YouTube adalah salah satu media sosial dengan situs web yang menyediakan berbagai macam video mulai dari video clip sampai film, serta video-video yang dibuat oleh pengguna YouTube itu sendiri.

YouTube merupakan salah satu media sosial yang sangat populer sekarang. Dimana sekarang banyak orang yang menggunakan YouTube sebagai tempat untuk berkarya terutama untuk anak muda. Rata rata anak muda yang menggunakan YouTube sebagai tempat berkarya adalah dengan membuat video video entah itu video lucu lucuan, romatis romantisan atau sebagainya. Orang orang yang menggunakan YouTube sebagai tempat berkarya mereka biasa di sebut YouTubers ("Mengenal Media Sosial Youtube - Kompasiana.Com” n.d.).

Maraknya YouTube membuat banyak perusahaan-perusahaan diluar sana menjadikan platform YouTube sebagai platform marketing mereka, termasuk juga klub-klub besar sepakbola yang ada di dunia. Football Money League telah merilis klub sepak bola terkaya pada 2020-2021. Lima daftar teratas dihuni oleh klub-klub tradisional yang memiliki basis massa besar di seluruh dunia. Pandemi Covid-19 memang menghantam seluruh sendi kehidupan, tak terkecuali sepak bola. Dibatasinya jumlah penonton yang datang ke stadion menampar stabilitas klub-klub di seluruh dunia. Bahkan, banyak klub yang di ambang kebangkrutan karena kesulitan finansial. Mereka harus mengatur keuangan dengan sangat hati-hati di situasi sulit ini. Meski begitu, klub-klub elite dunia terbukti masih mampu meraih pendapatan mewah pada musim 2020-2021. Berikut 5 klub sepak bola terkaya di dunia : Barcelona, Real Madrid, Bayern Munich, Manchester United dan Liverpool ("5 Klub Sepak Bola Terkaya Di Dunia, Nomor 1 Raup Rp12,2 Triliun - Sportstars.Id” n.d.).

Penelitian ini menggunakan metode eksploratif kuantitatif, dan akan menghitung menggunakan rasio-rasio yang ada pada YouTube. Pada penelitian (Permana 2021) menjelaskan bahwa terdapat 10 rasio yang ada pada sosial media YouTube dan relevan digunakan sebagai media ukur kredibilitas channel yang ada. Penelitian ini hanya berfokus untuk menghitung kredibilitas Dislikes to Viewers Ratio pada 5 Klub Sepakbola Terkaya di Dunia. Adapun 5 Klub Sepakbola Terkaya di Dunia, diantaranya yaitu : Barcelona, Real Madrid, Bayern Munich, Manchester United dan Liverpool ("5 Klub Sepak Bola Terkaya Di Dunia, Nomor 1 Raup Rp12,2 Triliun - Sportstars.Id" n.d.). Tujuan dari penelitian ini adalah mengetahui kredibilitas performa dari channel YouTube 5 Klub Sepakbola Terkaya di Dunia menggunakan Dislikes to Viewers Ratio. 


\section{TINJAUAN PUSTAKA}

Perkembangan bidang teknologi saat ini terjadi begitu pesat. Melalui perkembangan yang terjadi dari waktu ke waktu menimbulkan maraknya aplikasi-aplikasi serta platform media sosial yang bermunculan. Aplikasi yang sangat diminati oleh masyarakat saat ini diantaranya adalah TikTok, Instagram, Twitter, WhatsApp dan yang lain sebagainya. Seiring berjalannya waktu, aplikasi sosial media tersebut dapat menjadi candu bagi kalangan masyarakat. Tidak hanya kalangan remaja yang menggunakan aplikasi sosial media, orang tua bahkan anak-anak juga aktif menggunakan aplikasi sosial media tersebut ("Jurnal Analisis (Studi Kasus Rasio TikTok).Docx - Google Drive" n.d.).

YouTube dinobatkan sebagai media sosial terpopuler untuk masyarakat Indonesia. YouTube berhasil menjaring 170 juta pengguna atau 93,8 persen dari total keseluruhan populasi 181,9 juta pengguna internet berusia 16-64 tahun. Berdasarkan riset yang dilakukan Hootsuite dan We Are Social per Januari 2021, Senin (15/2/2021), pengguna internet berusia 16-24 tahun paling banyak menghabiskan waktunya menonton video online di perangkat mereka. Tercatat, 98,5 persen dari 181,9 juta populasi memilih beraktivitas di internet dengan menonton video online atau streaming. Artinya, 179,1 juta orang di Indonesia telah memanfaatkan internet untuk menonton video online. Selain itu, 74,3 persen dari total populasi atau 135,1 juta orang telah menghabiskan waktunya di internet untuk menonton vlog atau video blog. Sementara layanan streaming lain seperti musik telah menjangkau 84 persen pengguna atau 152 juta masyarakat Indonesia ("YouTube Rajai Media Sosial Di Indonesia” n.d.).

Youtube sendiri mulai berdiri semenjak bulan Februari 2005. Markas besar Youtube berada di San Bruno, California, Amerika Serikat yang diprakasai oleh tiga orang founder Youtube, yaitu Chad Hurley, Steven Chen, dan Jawed Karim. Website yang kini memuat miliaran video ini berkembang sangat pesat dari awal pertama kali didirikan. Pada tahun 2006 di bulan November, bahkan Google membeli Youtube dengan harga US\$1,65 miliar. Youtube mendapatkan penghasilannya dari iklan yang ditampilkan sebelum video-video youtube diputar. Iklan tersebut dinamakan dengan Google AdSense, sebuah program yang menawarkan pembayaran berdasarkan tingkat frekuensi sebuah video diputar. Pada bulan Februari 2017, tercatat bahwa ada video dengan total durasi 400 jam diunggah di Youtube setiap menitnya dan total satu miliar jam konten Youtube ditonton orang setiap harinya ("Pengertian YOUTUBE Adalah : Manfaat \& Fitur Youtube (Lengkap)" n.d.).

YouTube dirasakan memiliki kekuatan ataupun pengaruh dalam industri, sehingga menimbulkan kualitas channel yang menentukan strata maupun kredibilitas pemilik channel. Kredibilitas channel YouTube merupakan suatu hal yang cukup penting 
untuk berbagai kepentingan. Kredibilitas sebuah channel YouTube dapat diukur dari tingkat performa yang dihasilkan secara matematis. Dalam mengukur performa diperlukan skala pengukuran yang tertuang ke dalam rasio.

\section{METODE PENELITIAN}

Penelitian ini menggunakan metode eksploratif kuantitatif untuk mengetahui kredibilitas dari performa channel YouTube 5 Klub Sepakbola Terkaya di Dunia. Penelitian eksploratif adalah suatu jenis penelitian yang memiliki tujuan untuk melakukan eksplorasi atau memperdalam pengetahuan ataupun mencari ide-ide baru mengenai suatu hal tertentu, guna merumuskan permasalahan dengan secara lebih terperinci ataupun mengembangkan hipotesis dan bukanlah untuk menguji hipotesis ("Contoh Penelitian Eksploratif" n.d.).

Tujuan dari penelitian ini yaitu mengetahui nilai kredibillitas dari performa channel YouTube 5 Klub Sepakbola Terkaya di Dunia. Ada beberapa langkah yang harus dilakukan dalam penelitian ini, sehingga mampu menemukan peringkat pertama channel YouTube Klub Sepakbola Terkaya di Dunia yang memiliki performa terbaik. Langkah-langkah yang dilakukan pada penelitian ini, diantaranya yaitu :

1. Melakukan Eksplorasi Pada Website Untuk Menentukan Objek yang Akan Dianalisa.

Eksplorasi ini dilakukan pada beberapa halaman website yang menyediakan informasi mengenai objek yang akan di teliti. Setelah eksplorasi selesai dilakukan, sehingga ditemukan nama-nama klub sepakbola terkaya di dunia yang akan dijadikan objek analisa. Setelah melakukan eksplorasi pada halaman website, maka langkah selanjutnya yaitu mencari nama channel YouTube dari masingmasing klub sepakbola. Pastikan semua klub memiliki channel pada aplikasi sosial media YouTube.

2. Menghitung Nilai Rata-Rata Variable Dari 5 Klub Sepakbola Terkaya di Dunia.

Pada langkah ini, peneliti menghitung nilai variable dislikes dan variable viewers. Variabel merupakan salah satu komponen penting yang dibutuhkan peneliti dalam sebuah penelitian. Variabel mencakup segala sesuatu yang ditetapkan untuk mendapatkan informasi mengenai hal tersebut hingga bisa ditarik kesimpulannya ("Variabel Penelitian: Pengertian, Jenis, Dan Contohnya I Kumparan.Com" n.d.). Untuk menghitung nilai rata-rata dari variabel dislikes dan variabel viewers yaitu dengan cara mengambil minimal 10 postingan kemudian di hitung sehingga menemukan nilai rata-rata dari masing-masing variabel. 


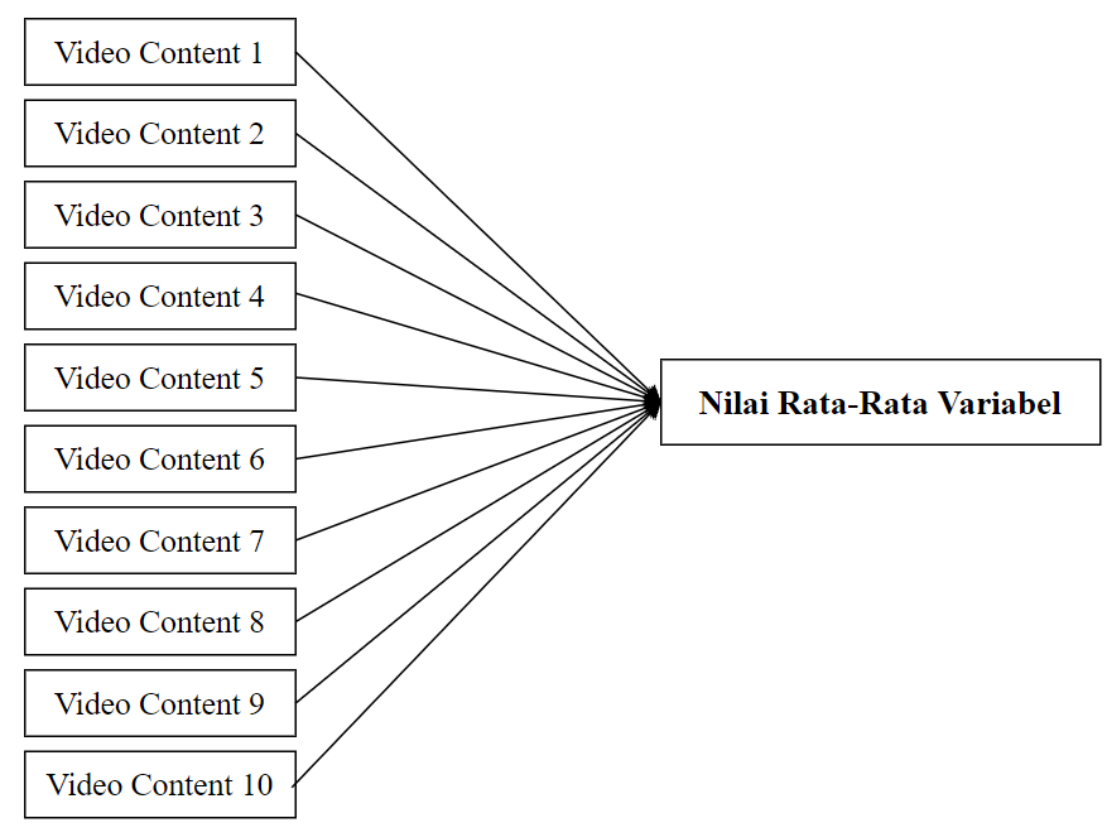

Gambar 1. Analisa Nilai Rata-Rata Variabel.

\section{Menghitung Nilai Kredibilitas Rasio}

Untuk menghitung nilai kredibilitas dari dislikes to viewers ratio, peneliti menggunakan cara membagi nilai variabel pertama dengan nilai variabel kedua. Jika dislikes memiliki nilai 100 dan viewers memiliki nilai 300, maka cara menghitungnya yaitu $100: 300=0,3$. Dengan begitu nilai dari dislikes to viewers ratio adalah 0,3 .

\section{Menentukan Peringkat Pada Channel YouTube}

Pada langkah terakhir yang dilakukan pada penelitian ini yaitu menentukan peringkat pada masing-masing rasio yang ada. Pada penentuan peringkat perlu melihat karakteristik dari rasio yang di teliti. Jika karakteristik rasio merupakan rendah, maka objek yang memiliki nilai terendah akan mendapatkan angka 5 dan objek yang memiliki nilai tertinggi akan mendapatkan angka 1. Namun jika rasio memiliki karakteritik tinggi maka objek yang mendapatkan nilai tinggi akan mendapatkan angka 5 dan objek yang mendapatkan nilai terendah akan mendapatkan angka 1. Setelah mendapatkan hasil kredibilitas ratio maka dapat disimpulkan objek yang mana mendapatkan peringkat 1 sampai dengan peringkat 5 .

\section{HASIL DAN PEMBAHASAN}


Channel YouTube dari 5 Klub Sepakbola Terkaya di Dunia, diantaranya :

1. Barcelona

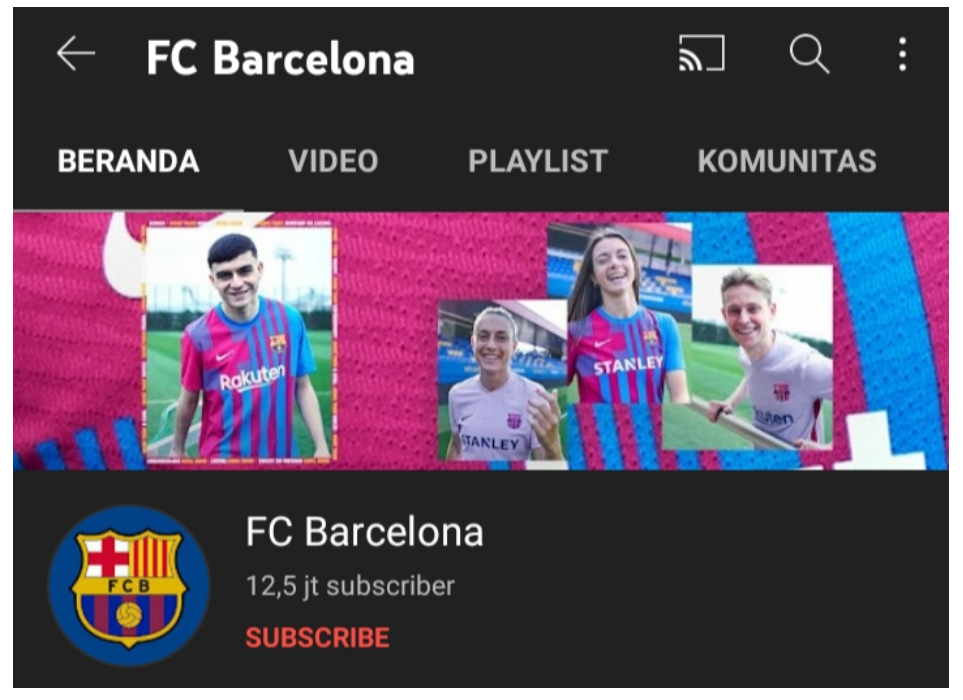

Gambar 1. Channel YouTube Barcelona

Sumber : https://youtube.com/c/FCBarcelona (akses pada 19-10-2021)

2. Real Madrid

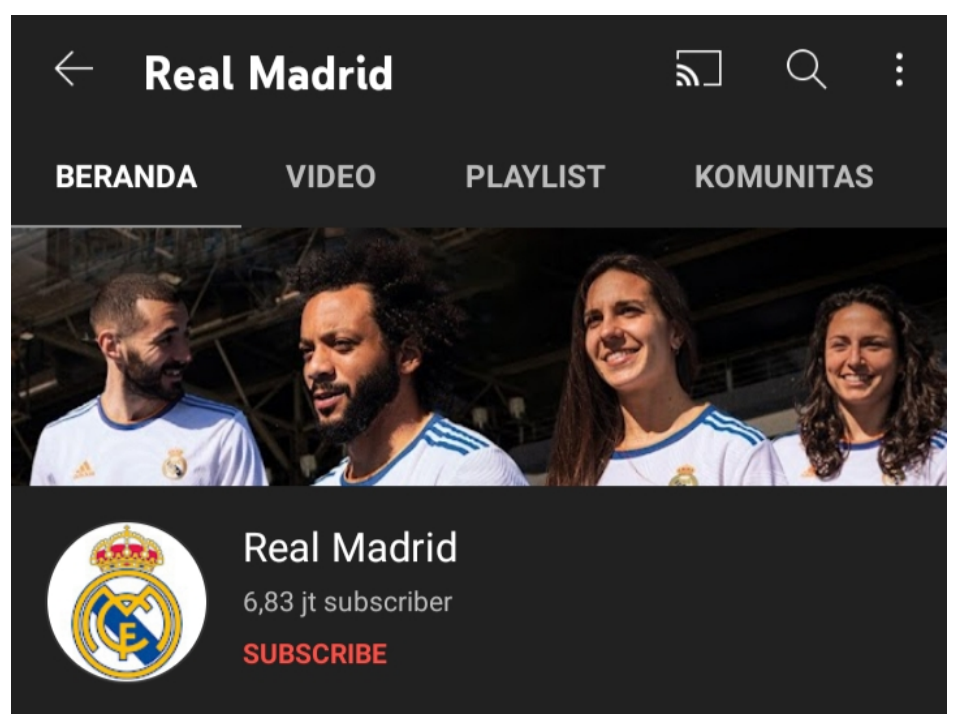

Gambar 2. Channel YouTube Real Madrid

Sumber : https://youtube.com/c/realmadrid (akses pada 19-10-2021)

3. Bayern Munich 


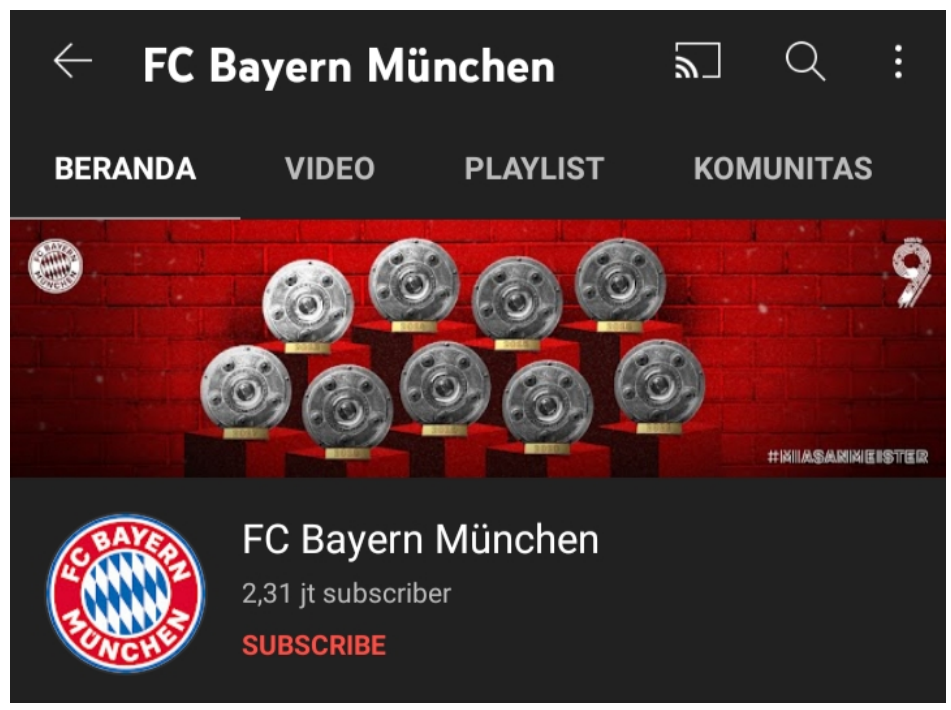

Gambar 3. Channel YouTube Bayern Munich

Sumber : https://youtube.com/c/fcbayern (akses pada 19-10-2021)

\section{Manchester United}

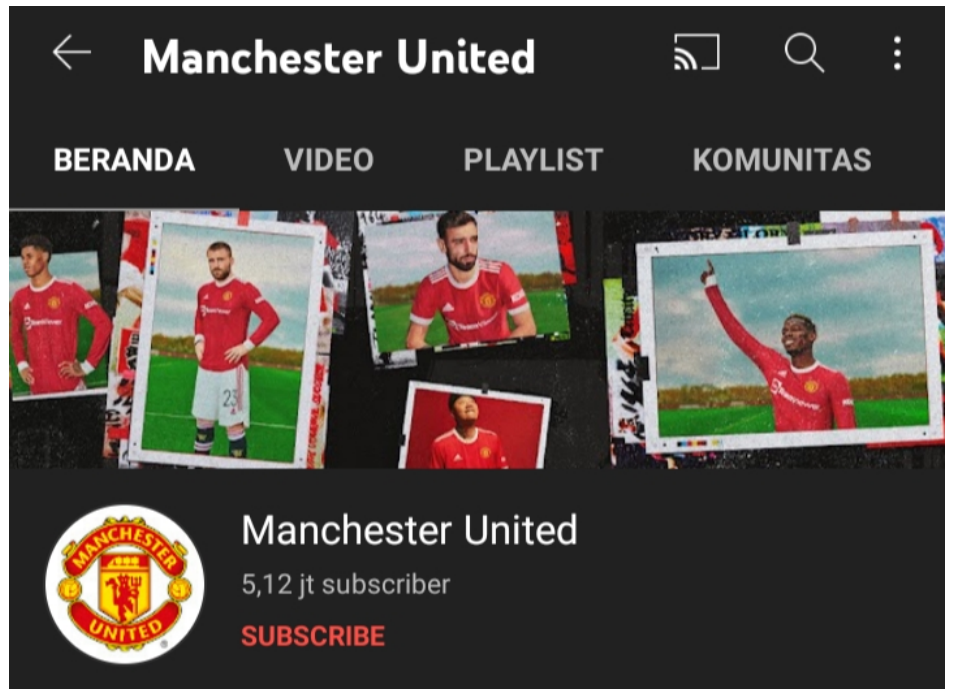

Gambar 4. Channel YouTube Manchester United

Sumber : https://youtube.com/c/manutd (akses pada 19-10-2021)

\section{Liverpool}




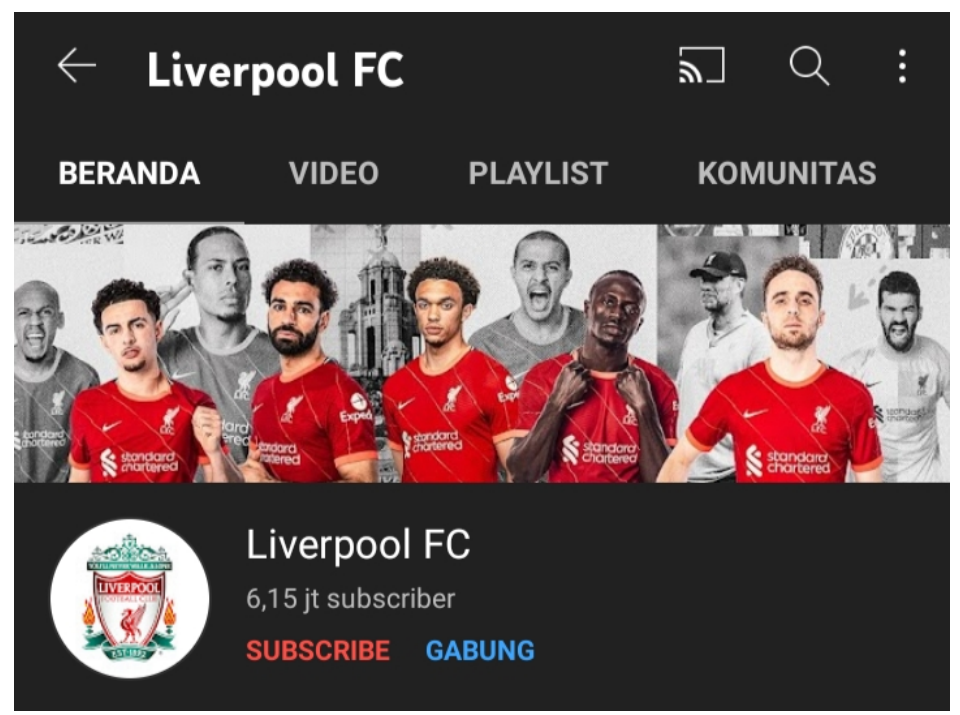

Gambar 5. Channel YouTube Liverpool

Sumber : https://youtube.com/c/LiverpoolFC (akses pada 19-10-2021)

Dari kelima channel YouTube 5 Klub Sepakbola Terkaya di Dunia, peneliti menemukan nilai dari masing-masing variabel yang ada untuk menghitung rasio Dislikes to Viewers dari setiap channel. Pada channel YouTube terdapat 6 variabel, diantaranya yaitu :

1. Post

2. Subscriber

3. Likes

4. Dislikes

5. Viewers

6. Comments

Dari keenam variabel tersebut peneliti hanya fokus untuk menemukan hasil dari 2 variable, yaitu :

1. Dislikes

2. Viewers

Dari kedua variabel tersebut kemudian dianalisa sehingga menemukan nilai ratarata dari variabel dislikes dan variabel viewers. Untuk menghitung nilai rata-rata dari variabel dislikes dan variabel viewers yaitu dengan cara mengambil minimal 10 konten videonya kemudian di hitung sehingga menemukan nilai rata-rata dari 
masing-masing variabel. Berikut merupakan tabel nilai rata-rata dari masingmasing klub sepakbola terkaya di dunia, yaitu :

Tabel 1. Analisa Nilai Rata-Rata Nilai Variabel Dislikes dan Viewers Channel YouTube Barcelona

\begin{tabular}{|c|c|c|}
\hline No & Dislikes & Viewers \\
\hline 1 & 60 & 33,000 \\
\hline 2 & 94 & 45,000 \\
\hline 3 & 67 & 65,000 \\
\hline 4 & 43 & 47,000 \\
\hline 5 & 145 & 67,000 \\
\hline 6 & 36 & 35,000 \\
\hline 7 & 160 & 199,000 \\
\hline 8 & 226 & 242,000 \\
\hline 9 & 176 & 87,000 \\
\hline 10 & 125 & 130,000 \\
\hline Total & 113 & 95,000 \\
\hline
\end{tabular}

Sumber : Pengolah Data Excel

Tabel 2. Analisa Nilai Rata-Rata Nilai Variabel Dislikes dan Viewers Channel YouTube Real Madrid

\begin{tabular}{|c|c|c|}
\hline No & Dislikes & Viewers \\
\hline 1 & 22 & 30,000 \\
\hline 2 & 59 & 99,000 \\
\hline 3 & 43 & 86,000 \\
\hline 4 & 152 & 106,000 \\
\hline 5 & 626 & 286,000 \\
\hline 6 & 73 & 139,000 \\
\hline 7 & 311 & 218,000 \\
\hline 8 & 86 & 168,000 \\
\hline 9 & 48 & 116,000 \\
\hline 10 & 107 & 138,000 \\
\hline Total & 153 & 138,600 \\
\hline \multicolumn{2}{|c|}{ Sumber : Pengolah Data Excel }
\end{tabular}


Tabel 3. Analisa Nilai Rata-Rata Nilai Variabel Dislikes dan Viewers Channel YouTube Bayern Munich

\begin{tabular}{|c|c|c|}
\hline No & Dislikes & Viewers \\
\hline 1 & 8 & 44,000 \\
\hline 2 & 152 & 86,000 \\
\hline 3 & 19 & 59,000 \\
\hline 4 & 15 & 61,000 \\
\hline 5 & 27 & 40,000 \\
\hline 6 & 28 & 69,000 \\
\hline 7 & 23 & 58,000 \\
\hline 8 & 89 & 214,000 \\
\hline 9 & 13 & 20,000 \\
\hline 10 & 30 & 80,000 \\
\hline Total & 30 & 73,100 \\
\hline
\end{tabular}

Sumber : Pengolah Data Excel

Tabel 4. Analisa Nilai Rata-Rata Nilai Variabel Dislikes dan Viewers Channel YouTube Manchester United

\begin{tabular}{|c|c|c|}
\hline No & Dislikes & Viewers \\
\hline 1 & 26 & 29,000 \\
\hline 2 & 29 & 59,000 \\
\hline 3 & 47 & 64,000 \\
\hline 4 & 15 & 27,000 \\
\hline 5 & 111 & 250,000 \\
\hline 6 & 33 & 50,000 \\
\hline 7 & 179 & 65,000 \\
\hline 8 & 23 & 37,000 \\
\hline 9 & 52 & 112,000 \\
\hline 10 & 2100 & 832,000 \\
\hline Total & 261 & 152,500 \\
\hline
\end{tabular}

Sumber : Pengolah Data Excel

Tabel 5. Analisa Nilai Rata-Rata Nilai Variabel Dislikes dan Viewers Channel YouTube Liverpool

\begin{tabular}{|l|l|l|}
\hline No & Dislikes & Viewers \\
\hline
\end{tabular}




\begin{tabular}{|c|c|c|}
1 & 32 & 142,000 \\
\hline 2 & 181 & 89,000 \\
\hline 3 & 49 & 29,000 \\
\hline 4 & 88 & 336,000 \\
\hline 5 & 257 & 660,000 \\
\hline 6 & 722 & $1,900,000$ \\
\hline 7 & 2400 & $5,400,000$ \\
\hline 8 & 1300 & $2,800,000$ \\
\hline 9 & 67 & 125,000 \\
\hline 10 & 389 & $1,300,000$ \\
\hline Total & 548 & $1,278,100$ \\
\hline
\end{tabular}

Sumber : Pengolah Data Excel

Setelah menghitung nilai rata-rata tersebut, maka akan menemukan hasil akhir nilai rata-rata dari variabel dislikes dan viewers.

Tabel 6. Nilai Variabel Pada Channel YouTube 5 Klub Sepakbola Terkaya di Dunia

\begin{tabular}{|l|c|l|l|l|c|}
\hline Variable & Barcelona & $\begin{array}{l}\text { Real } \\
\text { Madrid }\end{array}$ & $\begin{array}{l}\text { Bayern } \\
\text { Munich }\end{array}$ & $\begin{array}{l}\text { Manchester } \\
\text { United }\end{array}$ & Liverpool \\
\hline Dislikes & 113 & 153 & 30 & 261 & 548 \\
\hline Viewers & 95000 & 138600 & 73100 & 152500 & 1278100 \\
\hline
\end{tabular}

Sumber : Pengolah Data Excel

Pada channel YouTube terdapat 10 rasio yang relevan digunakan untuk mengukur kredibilitas pada masing-masing channel. Namun pada penelitian kali ini hanya berfokus untuk menghitung Dislikes to Viewers Ratio. Untuk menghitung kredibilitas dari masing-masing channel YouTube setiap klub sepakbola, peneliti menghitung dengan cara : variabel 1 akan dibagi dengan variabel 2 , sehingga ditemukan hasil analisis dari rasio tersebut.

Tabel 7. Hasil Perhitungan Rasio Channel YouTube

\begin{tabular}{|l|l|l|l|l|l|c|}
\hline No & RATIO & $\begin{array}{l}\text { Barcelon } \\
\text { a }\end{array}$ & $\begin{array}{l}\text { Real } \\
\text { Madrid }\end{array}$ & $\begin{array}{l}\text { Bayern } \\
\text { Munich }\end{array}$ & $\begin{array}{l}\text { Manchester } \\
\text { United }\end{array}$ & Liverpool \\
\hline & $\begin{array}{l}\text { Dislikes to } \\
\text { Viewers }\end{array}$ & $\begin{array}{c}0.001189 \\
5\end{array}$ & 0.0011039 & 0.0004104 & 0.0017115 & $\begin{array}{c}0.000428 \\
8\end{array}$ \\
\hline
\end{tabular}


Dislikes to Viewers Ratio memiliki karakteristik yang rendah, artinya semakin rendah nilai yang dihasilkan maka semakin baik kredibilitas dari performa channel tersebut. Untuk memberikan peringkat pada masing-masing Klub Sepakbola, peneliti memberikan angka 5 kepada klub yang mendapatkan nilai terendah dan angka 1 untuk klub sepakbola yang mendapatkan nilai tertinggi. Berikut merupakan tabel urutan nilai yang dihasilkan oleh masing-masing klub sepakbola.

Tabel 8. Nilai Rasio Channel YouTube 5 Klub Sepakbola Terkaya di Dunia

\begin{tabular}{|l|c|l|c|l|c|}
\hline \multirow{2}{*}{ RATIO } & \multicolumn{5}{|c|}{ NILAl } \\
\cline { 2 - 6 } & $\begin{array}{l}\text { Barcelon } \\
\mathrm{a}\end{array}$ & $\begin{array}{l}\text { Real } \\
\text { Madrid }\end{array}$ & Bayern Munich & $\begin{array}{l}\text { Manchester } \\
\text { United }\end{array}$ & Liverpool \\
\hline $\begin{array}{l}\text { Dislikes } \\
\text { to } \\
\text { Viewers }\end{array}$ & 2 & 3 & & & \\
\hline
\end{tabular}

Sumber : Pengolah Data Excel

Dari Tabel Nilai Rasio Channel YouTube 5 Klub Sepakbola Terkaya di Dunia dapat simpulkan bahwa Bayern Munich mendapatkan nilai tertinggi untuk rasio Dislikes to Viewers. Sedangkan channel YouTube Manchester United mendapatkan nilai terendah untuk rasio ini. Jadi, pada penelitian ini Bayern Munich memiliki kredibilitas performa yang lebih baik dibandingkan dengan klub sepakbola yang lainnya.

\section{KESIMPULAN}

Tujuan dari penelitian ini adalah mengetahui kredibilitas performa dari channel YouTube 5 Klub Sepakbola Terkaya di Dunia menggunakan Dislikes to Viewers Ratio. 5 Klub Sepakbola tersebut diantaranya : Barcelona, Real Madrid, Bayern Munich, Manchester United dan Liverpool. Dari kelima klub sepakbola tersebut dapat disimpulkan bahwa :

1. Peringkat pertama diraih oleh klub Bayern Munich dengan nilai terendah yaitu 0.0004104

2. Peringkat kedua diraih oleh klub Liverpool dengan nilai 0.0004288 
3. Peringkat ketiga diraih oleh klub Real Madrid dengan nilai 0.0011039

4. Peringkat keempat diraih oleh klub Barcelona dengan nilai 0.0011895

5. Peringkat kelima diraih oleh klub Manchester United dengan nilai tertinggi yaitu 0.0017115

\section{DAFTAR PUSTAKA}

“5 Klub Sepak Bola Terkaya Di Dunia, Nomor 1 Raup Rp12,2 Triliun - Sportstars.Id.” n.d. Accessed October 20, 2009. https://www.sportstars.id/read/5-klub-sepak-bolaterkaya-di-dunia-nomor-1-raup-rp12-2-triliun-Wu631B.

"Contoh Penelitian Eksploratif." n.d. Accessed October 20, 2009. https://www.detik.com/edu/detikpedia/d-5529159/contoh-penelitian-eksploratif.

“Jurnal Analisis (Studi Kasus Rasio TikTok).Docx - Google Drive." n.d. Accessed October 21, 2009.

https://drive.google.com/file/d/1aGga6IC6RkoCEu0leJMkVuq6rRP9Y1B5/view.

"Mengenal Media Sosial Youtube - Kompasiana.Com." n.d. Accessed October 20, 2009. https://www.kompasiana.com/sesarrrrr/584a24c506b0bd7a0732fdf7/mediasosial-youtube.

"Pengertian YOUTUBE Adalah : Manfaat \& Fitur Youtube (Lengkap)." n.d. Accessed October 20, 2009. https://www.nesabamedia.com/pengertian-youtube/.

Permana, I Putu Hendika. 2021. "Analisis Rasio Pada Akun Youtube Untuk Penelitian Kualitatif Menggunakan Metode Ekploratif." Jurnal Ilmiah Media Sisfo 15 (1): 40-48. https://doi.org/10.33998/MEDIASISFO.2021.15.1.970.

"Variabel Penelitian: Pengertian, Jenis, Dan Contohnya | Kumparan.Com." n.d. Accessed October 21, 2009. https://kumparan.com/berita-hari-ini/variabel-penelitianpengertian-jenis-dan-contohnya-1ul9vdTWwAS.

"YouTube Rajai Media Sosial Di Indonesia." n.d. Accessed October 20, 2009. https://www.suara.com/tekno/2021/02/15/153000/youtube-rajai-media-sosial-diindonesia. 